interests are shared by $\mathrm{NIH}$, might then decide to lobby for the agency's entire budget. Yet even this plan may backfire; the groups may instead use the current NIH figure as a base and simply lobby for a hefty increase on top of that.

In the meantime, Congress is attacking the problem by looking at its own practices. Its first priority is controlling pork, but it also wants to see the money spent wisely. Brown has proposed several changes to the rules under which Congress operates that would make the most flagrant pork easier to kill, including an opportunity for legislators to raise objections during the appropriations process and the inclusion of a "pork watchdog' in appropriations conferences. He and others have promised to give pork a run for its money next year, assuming that voters reelect them this week.

Another example is a $\$ 20$-million earmark for a AIDS vaccine trial in the Senate defence bill. In previous years, this language, which is intended to apply only to a gp160 vaccine made by MicroGeneSys, Inc. of Meriden, Connecticut, might have simply been approved as unaltered pork. But this year, in a modest concession to the scientific process, legislators decided to allow the NIH director, the director of the Food and Drug Administration and the secretary of defence to review the expenditure and spend the money elsewhere if they do not think that the trial should proceed.

It is not a coincidence that one of the authors of the amendment is Senator Sam Nunn (Democrat, Georgia), the chairman of the Armed Forces Committee and traditionally one of the strongest voices against earmarking. Although Nunn had no more success than Brown in removing pork from this year's defence budget, he was able to moderate it with a technique he hopes to repeat. Some $\$ 75$ million worth of earmarked projects cannot be released until they have passed a merit-review process based on the potential contribution each project would make "to the national scientific and technical posture".

Unfortunately, even that language has become controversial. In deference to Senator Daniel Inouye (Democrat, Hawaii), a member of his committee, Nunn stipulated that the reviewers should be from institutions that belong to the National Association of State Universities and Land Grant Colleges or the American Association of State Colleges and Universities. Although that group includes the University of Hawaii, in Inouye's home town, it excludes all 58 members of the Association of American Universities, which includes most of the largest US research universities.

Nevertheless, most legislators believe that some sort of merit review is better than none at all. And researchers are hoping that the money for earmarking, even if it is here to stay, will go towards the best science.

Christopher Anderson

\title{
Japan wants global guidelines for joint research projects
}

Tokyo, Washington \& Munich. In another example of 'technoglobalism', Japan's Ministry of International Trade and Industry (MITI) is trying to persuade the world's leading nations to agree on guidelines for international industrial research and development projects. But the proposal, put forward at a meeting of the Organisation of Economic Cooperation and Development (OECD) in Paris on 19-20 October, has left Western nations perplexed.

As a counterweight to moves by the United States to protect its industrial intellectual property rights - known in Japan as 'technonationalism' - MITI has tried in recent years to encourage advanced nations to establish international industrial research and development projects. One example is the Intelligent Manufacturing Systems (IMS) project to develop the automated factories of the future, which MITI unveiled in 1990 to an unsuspecting world (see Nature 343, 496; 1990).

The project is an attempt to direct the resources of the world's most advanced companies and research laboratories towards sophisticated computerized manufacturing systems, but it met stiff opposition from the United States and Europe on such issues as intellectual property rights. A feasibility study is finally under way after two years of negotiations (see Nature 355, 755; 1992).

The difficulties with IMS encouraged MITI to make its latest proposal. "The guidelines/checklists could provide model procedures to start an international project [with] example agreements to be adopted and model arrangements for intellectual property rights" says the proposal to the OECD's Committee on Science and Technology Policy.

Thomas Ratchford, associate director for international affairs at the White House Office of Science and Technology Policy and part of the US delegation at the OECD meeting, says the Japanese proposal "is not very carefully defined". European delegates agree that the proposal is vague, and Japan has been asked to revise it for a meeting this winter. "We agree in principle with their approach", says William Booher of the Technology Administration within the US Commerce Department, "but there were real concerns about some of the substance".

One problem raised by the Western nations is the idea of applying guidelines to what are essentially unique ventures. "What the Japanese seem to want, for example", says Ratchford, "is a standard IPR [intellectual property rights] clause that can be pulled off the shelf and inserted into a new technology agreement. But it does not work that way."

Another problem arises from the differ- ing relationships between government and industry in each country. Whereas MITI launches national projects to encourage Japanese companies to develop commercial technologies, the US government adopts much more of a 'hands-off' approach (except perhaps in the area of defence), leaving companies to form their own collaborations.

Masaya Yasui, deputy director of MITI's technology policy research and analysis division at the Agency of Industrial Science and Technology, accepts that the proposal has caused "misunderstandings". "People fear the guidelines may have restrictive power", he says. "We do not want to stimulate such anxiety. However, it's easy to point out differences [between countries and projects]. Surely it's much more productive to find common principles".

Japan also wants to improve communications between nations so that the world learns about new technology projects as early as possible. For example, Korea is unhappy that it was not included in the IMS project, and Japan feels that it is not well informed about European-based international projects.

European delegates agree that it will be very useful if the Japanese proposal establishes rules for joint projects and creates a mechanism for explaining their purpose. According to an OECD spokesman, Japan encounters such problems every time it seeks international partners.

Japan's proposal was not the only one made at last month's OECD meeting. The United States suggested a study of government-supported programmes on critical technologies to move forward in parallel with the Japanese initiative. Both would be coordinated by a working group on technology policy first proposed 18 months ago by the United States. It is likely that the proposals would be linked with an effort already underway to establish guidelines for international big-science projects such as the US space station and the Superconducting Super Collider. The Japanese say that they are confused by the timing of the US proposal, which US officials see as a "logical next step" in proposing future joint projects.

All these efforts will take some time to bear fruit. The OECD is not inclined to act quickly; its preferred style is lengthy discussion, followed by an analysis of the issue culminating in a report that may form the basis for action. In addition, such activities require the $\mathrm{OECD}$ to solicit contributions from member countries to supplement its meagre resources, and making those financial arrangements also takes time.

David Swinbanks, Jeffrey Mervis

\& Alison Abbott 